\title{
Relationship between soil properties and forests carbon: Case of three community forests from Far Western Nepal
}

\author{
H. P. Pandey ${ }^{1}$, P. Pandey ${ }^{2}$, S. Pokhrel ${ }^{3}$ and R. A. Mandal ${ }^{4}$
}

The study was carried out in three community-managed forests of Dadeldhura district located in Far West of Nepal in 2015. The objectives of the study were to analyze biomass and soil organic carbon (SOC) accumulation and observe how primary soil nutrients and other soil properties affect the biomass and SOC in these forests. Simple random sampling method was used with $0.62 \%$ sampling intensity. Concentric circular sample plot of various sizes were laid out for the necessary data collection. ANOVA, Tukey's HSD and correlation tests were performed. The carbon density differed significantly $(p<0.05)$ in the studied CFs. The Tukey's test showed the BPCF had significantly higher $(p<0.05)$ carbon density than other CFs. The correlation between biomass density ( $\mathrm{t} / \mathrm{ha}$ ) and soil bulk density was very weak and it was not significant. However, biomass density revealed significant $(p<0.05)$ negative correlation with SOC $(r=-0.38)$ and Phosphorous $(r=-0.56)$ content in the soil. Biomass density had no significant correlation with rest of the parameters. Similarly, SOC had significant $(p<0$. $05)$ positive correlation with all the parameters except with soil bulk density $(p<0.05, r$ $=-0.88$ ). Despite the higher biomass in forests, we found the lesser amount of SOC and primary soil nutrients in the soil. Similarly, acidic soils with higher contents of primary soil nutrients (NPK) had relatively higher SOC whereas higher bulk density decreased the SOC content. Results revealed that community-managed forests seemed a viable source of biomass production and carbon sink to combat the global environmental problem (global warming). These types of forests have conserved relatively the higher biomass (biomass carbon) than normally (business-as-usual) managed forests. This output would be a reference to the policy maker, national and international communities of diverse fields who are engaged in forest carbon services related activities such as reducing emission from deforestation and forest degradation (REDD), clean development mechanism (CDM) and forest management in terms of production. Similar studies are recommended in larger geographical areas and different ecological zones to generalize the inference.

Keywords : Biomass density, community-managed forests SOC, soil nutrients

$\mathrm{T}$ he effects of climate change have become obvious in the natural environment together with other threats like habitat destruction, fragmentation, disturbance and loss of biodiversity (Lepetz et al., 2009). Signs of global warming are evident from receding mountain snowlines and glaciers, shrinking ice cover on lakes and rivers in winter, melting polar sea- ice, migration patterns of birds and animals, changes in agriculture seasons and migration of lowland ecosystems to higher altitudes where forests can be both sources and sinks of carbon, depending upon the specific management regime and activities (IPCC, 2000).

Carbon stock is defined as the amount of carbon stored in the world's forest ecosystem which is mainly in living biomass, soil and to a lesser

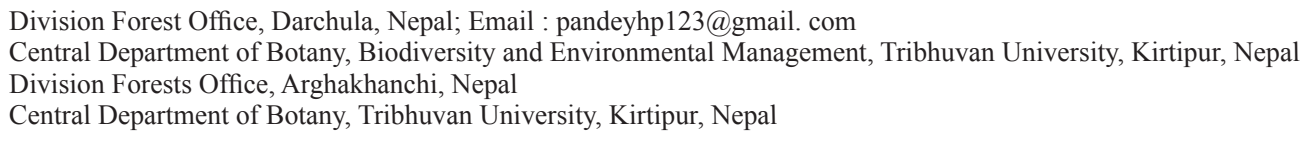


extent also in deadwood and litter, and carbon sequestration is the process of increasing the carbon content of a carbon pool other than the atmosphere (FAO, 2011).

Carbon accumulations in forest ecosystems involve numerous components including biomass carbon and soil carbon. The world's forests and forests' soils currently store more than one trillion tons of carbon which is twice the amount floating free in the atmosphere (Oli and Shrestha, 2009), just over half of the carbon residing in terrestrial ecosystems (FAO, 2001) and act as natural storage for carbon at the global scale, contributing approximately $80 \%$ of terrestrial above ground and $40 \%$ of terrestrial below ground carbon storage (Kirschbaum, 1996). Soils also play an important role as the largest pool of terrestrial organic carbon in the global carbon cycle. Globally, approximately $1500 \mathrm{Pg}$ of carbon are stored in soils in the form of organic matter, approximately twice the atmospheric pool (Jin et al., 2000) which is a win-win strategy for developing countries, where land use change and agricultural intensification is most frequent (Lal, 2004). Rapidly rising concentrations of atmospheric carbon dioxide $\left(\mathrm{CO}_{2}\right)$ have prompted a flurry of studies on soils as potential carbon (C) 'sinks'. About $70 \%$ of this $\mathrm{C}$ is stored in the soil (Dixon et al., 1994).

The trees store carbon by sequestrating atmospheric carbon in the growth of wood biomass through the process of photosynthesis and thereby increasing the soil organic carbon (Brown and Pearce, 1994). In reality, the forest is a reservoir, a component or component of the climate system where green house gases are stored, as well as sink, any process that removes a greenhouse gas (GHG) from the atmosphere (Pearce et al., 2003) and it is varied according to geographical location, plant species and age of the stand (Van Noordwijk et al., 1997; Shrestha and Singh, 2008), climatic conditions, soil type, aspect and density (Shrestha and Singh, 2008). The rate of carbon accumulation and its distribution in soil profile differ between tree species, for example, soils in a forestation areas accumulate less carbon and at a slower rate than the above ground biomass (Jandle et al., 2007) in the intact forests. In fact its amount depends on the above ground input received from leaf litter and on the decomposition of fine roots below ground (Rasse et al., 2006). Forest soil tends to accumulate more carbon than soil does under agriculture, because the carbon turns over more slowly (Guggenberger et al., 1994). Thus, forest soils may store more carbon than agricultural soils and their responses to increasing atmospheric $\mathrm{CO}_{2}$ concentrations will be significant for the future global carbon cycle. Vegetation and soils are viable sinks of atmospheric $\mathrm{C}$ and may significantly contribute to mitigation of global climate change (Bajracharya et al., 1998).

In Nepal, information on carbon stocks density at different forests' ecosystem is still insufficient. Inventory of forest and soil has been paid little attention regarding the carbon that it sequestrated, hence, amount of soil and biomass carbon sequestrated is unknown (Shrestha, 2008) for many forests. Moreover, in case of Far Western region, it is the least researched area of Nepal in this context (Lamsal et al., 2018). The constitution of Nepal, 2015 envisioned that carbon is a service. After amendment of prevailing Forest Act (1993), carbon is recognized as an ecosystem service which is the first legalized document that emphasized that carbon has some economic value. Further, with the enactment of Forest Act (1993), community forestry (CF) has been accorded the highest priority programme of the Nepal's forestry sector and its subsequent amendment incorporates that carbon is an ecosystem service within the community forests too. Thus, community forests should have baseline data on how much carbon credit they possess based on scientific inventories from which more than 20,000 communities and more than 2.2 million ha of forests could be benefited (DoFSC, 2018). Realizing the high carbon sinks in the forests by UNFCCC (2010), it is deemed necessary to account the carbon of individual forests. Therefore, this study has realized the estimation of biomass and soil carbon accumulation in community forests. The objectives of the study were to analyze biomass and soil organic carbon (SOC) accumulation and observe how primary soil nutrients and other soil properties affect the biomass and SOC in three community-managed forests of Dadeldhura district Far West Nepal.

\section{Materials and methods}

\section{Study area}

Dadeldhura district lies in Province No. 7, covers an area of $1,538 \mathrm{~km}^{2}$, located between 
28. $59^{\circ}$ to $29.26^{\circ} \mathrm{N}$ latitude and $80.12^{\circ}$ to 80 . $47^{\circ} \mathrm{E}$ longitude. It is $798 \mathrm{~km}$ west of capital city Kathmandu and the population was 142, 094 in 2011. The altitudinal range of the district is $462 \mathrm{~m}$ asl to $2639 \mathrm{~m}$ asl. The climate of the district is divided into four zones, namely, lower tropical (below $300 \mathrm{~m}$, upper tropical (300-1000 $\mathrm{ml})$, sub- tropical $(1000-2000 \mathrm{~m})$ and temperate (2000-3000 m), constituting an area of $0.6 \%, 34$. $7 \%, 55.8 \%$, and $8.9 \%$, respectively (https ://en. wikipedia. org/wiki/DadeldhuraDistrict). Climate and natural vegetation of the district are quite varied due to variation in landscape and elevation. The average maximum temperature is $32.7^{\circ} \mathrm{C}$ and average minimum temperature $13.6^{\circ} \mathrm{C}$ and average annual rainfall of $1343.6 \mathrm{~mm}$ (DHM, 2016). The study area is located in Bhimdatta Municipility of the Dadeldhura district.

\section{Community forests}

The formal handover of CF in the district was commenced in 1991. The district comprises more than $450 \mathrm{CFs}$. The study was carried out in Rishikhola Mahila Community Forest, Baisyadharghatal Patihalna Community Forest and Dhobikhola Community Forest (Fig. 1).

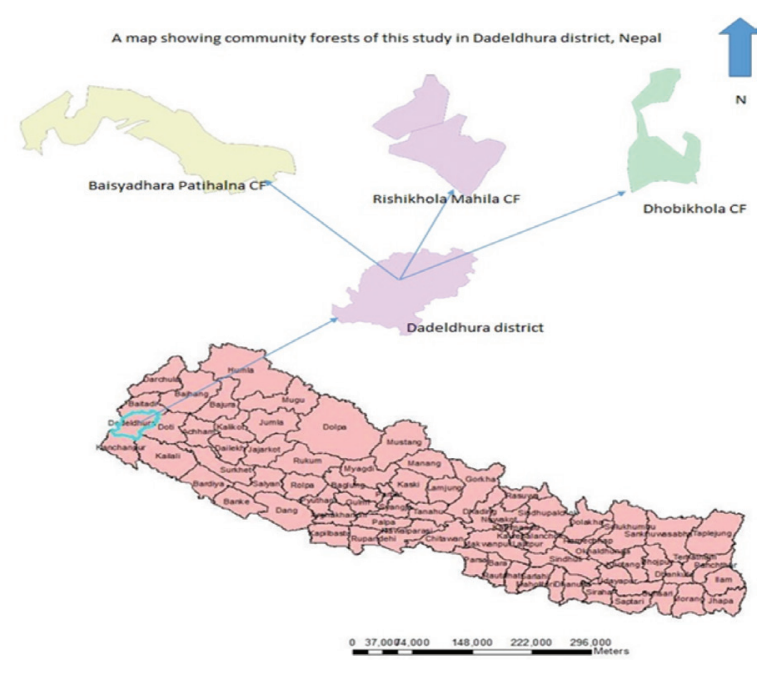

Fig. 1: A map showing study area

\section{Rishikhola Mahila Community Forest (RMCF)}

This forest is located in ward number 5 of Amargadhi Municipality in Dadeldhura district. The total forest area is 66.26 ha and the altitude of forest ranges from about 868. 16-1654. 29 $\mathrm{m}$. The forest was formally handed over as
CF in July1994. The Community Forest User Group (CFUG) was awarded with Sarbamanya Ganeshman Singh Forest Conservation Prize in 5 June 1999 for its contribution in CF conservation and management. The forest is located in north-eastern aspect dominated by Quercus leucotrichophora. Major associated species are Myrica esculenta, Q. lanata, Rhododendron arboreum, Pyrus pashia, Castanopsis tribuloides, Pinus roxburghii, Pinus patula, Lyonia ovalifolia and Saurauia napaulensis. The forest area per house hold is 0.3 ha. The number of households is 244 and the benefited population is 1633 . The major ethnic groups are Brahmin and Chhetri.

\section{Baisyadharghatal Patihalna Community Forest (BPCF)}

The forest is located in ward number 2 of Amargadhi Municipality in Dadeldhura district. The total area of the forest is 60.75 ha and altitudinal range of the $\mathrm{CF}$ is from 1623. 56$1866.05 \mathrm{~m}$. The forest was formally handed over as CF in July 1993. The forest is dominated by Q. leucotrichophora, which is located in southern aspect. The disturbance in this forest is more than the Rishikhola Community Forest. The major associate species are M. esculenta, Q. lanata, $R$. arboreum, P. pashia, L. ovalifolia, P. roxburghii and $S$. napaulensis. The number of households is 152 and the benefited population is 936. The major ethnic groups' are Brahmin and Chhetri. The forest area per house hold is 0.4 ha.

\section{Dhobikhola Community Forest (DKCF)}

The forest is located in ward number 5, Jhurkali of Amargadi Municipality in Dadeldhura district. The total area of the forest is 55.41 ha and altitude of the forest ranges from $1400-1840 \mathrm{~m}$. It was formally handed over as CF in 2014. The forest is located in west aspect and is dominated by $P$. roxburghii. Major associated species are $Q$. leucotrichophora, Q. lanata, $R$. arboreum, M. esculenta, $S$. napaulensis and $P$. patula. The number of households is 38 and the benefited population is 265 . The major ethnic groups are Brahmin and Chhetri.

\section{Data collection}

The major data collection was carried out in the last of 2015. Reconnaissance survey at the end of 
forest area was done to collect general information of the community forests. Altogether 45 samples, 15 from each $\mathrm{CF}$, were collected from three community forests. The map of the study area was prepared using GPS and the sample plots were distributed randomly. Then, the coordinates of sample plots were uploaded in GPS. Finally, the sample plots were located and laid out.

\section{Forest sampling and inventory}

Simple random sampling method with $0.62 \%$ sampling intensity was used for collecting data of tree biomass. A concentric circular sample plots (CCSP) of radius $8.92 \mathrm{~m}$ were laid out. Within each plot, three sub-plots were established for specific purposes. Inside the $8.92 \mathrm{~m}$ radius plot, a sub-plot with a radius of $5.64 \mathrm{~m}$ was established for saplings, a sub-plot with a radius of $1 \mathrm{~m}$ for counting regeneration and a sub-plot with a radius of $0.56 \mathrm{~m}$ radius for collecting samples of soil, leaf litter, herbs and grass (Fig. 2).

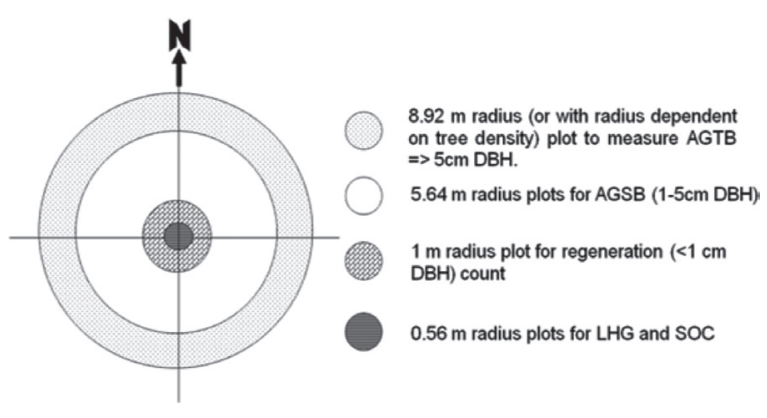

Fig. 2: Design of sample plot (Source : ANSAB, 2010)

\section{Measurement in sample plots}

Diameter at breast height (DBH) at $1.3 \mathrm{~m}$ and total height of all trees, poles and saplings were measured using diameter-tape (D-tape) and clinometers in respective sample plots. All herbaceous and woody vegetation were clipped from a sub-plot of $0.56 \mathrm{~m}$ radius and collected separately to take their fresh weights. The representative samples of 300 grams of both leaf litter and herbaceous vegetation were taken and brought to the laboratory for oven drying.

\section{Soil sampling}

The standard procedure (ANSAB, 2010) of collecting soil samples was followed for soil organic carbon assessment. Soil samples were collected at different depths in three layers $(0-10 \mathrm{~cm}, 10-20 \mathrm{~cm}$ and $20-30 \mathrm{~cm})$ from each sub-plot. A core ring sampler $(5 \mathrm{~cm}$ diameter and $10 \mathrm{~cm}$ long) was used for taking soil samples to estimate bulk density.

\section{Data analysis}

Data were analyzed by using the guidelines developed by ANSAB (2010). The predictive allometric equations (models) developed by Chave et al. (2005) were used for estimating Above-ground Tree Biomass (AGTB). The biomass stock density of a sample plot was converted to carbon stock density using IPCC (2006) default carbon fraction of 0. 47. Sapling $(\mathrm{dbh}<5 \mathrm{~cm})$ biomass was calculated by using biomass tables compiled by Tamrakar (2000). Soil organic carbon was calculated using Pearson et al. (2007). To simplify the process for estimating below-ground biomass, we used MacDicken (1997) root-to-shoot ratio value of $1: 5$. Biomass on leaf litter, dead wood, stumps was estimated in the laboratory. The cumulative value provided the total biomass from the forests. SOC and NPK constituents were analyzed in the laboratory. The soil carbon percent, bulk density, soil $\mathrm{pH}$ were analyzed in the soil laboratory of the Agriculture Technology Center, Lalitpur, Nepal.

ANOVA and Tukey's HSD tests were performed to see the differences in carbon density. A correlation test was performed to observe the relationship between biomass ( $\mathrm{t} / \mathrm{ha}$ ) and soil bulk density, SOC, soil $\mathrm{pH}$, soil $\mathrm{N} \%, \mathrm{P}(\mathrm{kg} / \mathrm{ha})$ and $\mathrm{K}$ $(\mathrm{kg} / \mathrm{ha})$ content in the soil. Similarly, correlation test between SOC and soil $\mathrm{pH}$, soil bulk density, $\mathrm{N}, \mathrm{P}$ and $\mathrm{K}$ were performed. All the analysis and tests were performed in $\mathrm{R}$ version 3. 5. 2 (R Core Team, 2018).

\section{Results and discussion}

\section{Forest status}

Mixed types of forest were found in the study area. The density of trees varied in the studied CFs. RMCF had 1635 trees per hectare, BPCF consisted of 1048 trees per ha and DKCF comprised 1270 trees per ha.

P. roxburghii trees were found to be the largest in size in RMCF and BPCF while $R$. arboreum were the smallest in size in these CFs. But P. patula 
trees were found to be the largest in size in DKCF. The diameter of different species in DKCF varied considerably. There was slight variation in mean height of different species in RMCF and BPCF (Table $1)$.

Table 1 : Mean height and diameter of major species in the studied CFs

\begin{tabular}{|l|l|c|c|c|c|c|c|}
\hline \multirow{2}{*}{ Local name } & \multirow{2}{*}{ Scientific name } & \multicolumn{3}{|c|}{ Mean DBH (cm) } & \multicolumn{3}{c|}{ Mean height (m) } \\
\cline { 3 - 8 } & & RMCF & BPCF & DKCF & RMCF & BPCF & DKCF \\
\hline Sano Banjh & Quercus leucotrichophora & 13 & 14 & 13 & 9 & 10 & 8 \\
\hline Thulo Banjh & Quercus lanata & 14 & 12 & 10 & 10 & 9 & 8 \\
\hline Laligurans & Rhododendron arboreum & 11 & 12 & 8 & 7 & 7 & 6 \\
\hline Khote Salla & Pinus roxburghii & 20 & 21 & 26 & 12 & 12 & 14 \\
\hline Pate Salla & Pinus patula & 18 & 17 & 31 & 11 & 11 & 15 \\
\hline $\begin{array}{l}\text { Musure } \\
\text { Katus }\end{array}$ & Castanopsis tribuloides & 20 & - & - & 12 & - & - \\
\hline Kafal & Myrica esculenta & 13 & 15 & 12 & 7 & 9 & 8 \\
\hline
\end{tabular}

\section{Biomass and carbon stock density}

Forest biomass is the total weight of biologically produced materials in an over-dried state. The biomass stock density of three community forests is shown in table 2.

Table 2 : Above and below ground biomass of the community forests

\begin{tabular}{|l|c|c|c|c|c|c|c|}
\hline $\begin{array}{l}\text { Community } \\
\text { forest }\end{array}$ & $\begin{array}{c}\text { AGTB } \\
\text { (t/ha) }\end{array}$ & $\begin{array}{c}\text { AGSB } \\
(\mathbf{t} / \mathbf{h a})\end{array}$ & $\begin{array}{c}\text { AGLHGB } \\
\mathbf{( t / h a )}\end{array}$ & $\begin{array}{c}\text { Total AGB } \\
\mathbf{( t / h a )}\end{array}$ & $\begin{array}{c}\text { BGB } \\
\mathbf{( t / h a )}\end{array}$ & $\begin{array}{c}\text { Total } \\
\text { biomass } \\
\mathbf{( t / h a )}\end{array}$ & $\begin{array}{c}\text { Total } \\
\text { biomass } \\
\text { carbon (t/ha) }\end{array}$ \\
\hline DKCF & 140.48 & 0.16 & 0.22 & 140.86 & 28.09 & 168.95 & 79.39 \\
\hline RMCF & 148.80 & 0.53 & 0.50 & 149.83 & 29.76 & 179.59 & 84.44 \\
\hline BPCF & 234.79 & 0.41 & 0.55 & 235.75 & 46.95 & 282.70 & 132.87 \\
\hline $\begin{array}{l}\text { AGTB- Above ground tre biomass AGSB- Above ground sapling biomass AGLHGB- Above } \\
\text { ground leaf, herbs and grass biomass AGB- Above ground biomass BGB- Below ground biomass }\end{array}$ \\
\hline
\end{tabular}

The highest mean values of AGTB and AGLHGB were found in the BPCF, which were 234.79t/ha and $0.55 \mathrm{t} / \mathrm{ha}$, respectively (Table 2 ). Similarly, the highest AGSB (0.53 t/ha) was found to be in the RMCF. The lowest AGTB, AGSB and AGLHGB in DKCF were $140.48 \mathrm{t} / \mathrm{ha}, 0.16 \mathrm{t} / \mathrm{ha}$ and $0.22 \mathrm{t} /$ ha, respectively. The highest AGB in BPCF was found to be 235.75t/ha. Similarly, the lowest mean value of AGB in the DKCF was found to be $140.86 \mathrm{t} /$ ha (Table 2). Respective hierarchy of quantity of BGB was found as a conversion that form 0.20 proportion (Table 2). In a national inventory (2010-2014), the biomass density in the Mid-hills region was 138.61 t/ha (DFRS, 2015a). The relatively higher biomass density in the studied CFs reveals the better management of the community forests which may have facilitated to accumulate larger amount of biomass. As a result, the CFs received a renounced national conservation prize in the past year. The above ground biomass of the forest depends on the age of the forest, density of the forest, types of species and wood species density. Thus, the highest value of biomass was found in the BPCF due to relatively older trees composition (greater diameter and height of the trees). The major pool of carbon in the forest is supposed to be the biomass of its all forms.

\section{Soil organic carbon, bulk density and pH}

The soil is considered as almost permanent stocking source of carbon. However, soil inside the forests has greater influences by the vegetation 
that grows on it. The soil organic carbon and bulk density of three community forests are given in table 3 .

The highest SOC density was found in RMCF $(99.23 \mathrm{t} / \mathrm{ha})$ followed by BPCF (74.79 $\mathrm{t} / \mathrm{ha})$ and the least was in DKCF (69.67 t/ha). The visual observation showed that the highest SOC in the RMCF may be due to higher amount of leaf litter accumulation on the forest floor. Users had hardly collected the leaf litter from the forest. As a result the leaves and twigs decomposed and added organic matter into the soil. The SOC reduced with the increase in depths of the soil in all three CFs. Similar results were found in the National Forest Inventory (2010-2014) in Midhills of Nepal (DFRS, 2015a). The relationship of soil bulk density and SOC was found reciprocal (Table 3) and it was significant (Table 4). Soil pH was found to be acidic in nature in the studied $\mathrm{CFs}$ and the values were almost the same. Washout of basic ions in the sloppy land resulted $\mathrm{H}^{+}$-rich ions in the soil and more acid released by the decomposition of organic residues may be the outcome of this figure. These results are comparable with the DFRS (2015a) SOC stock of Middle Mountains region of Nepal. The overall average SOC stock $(54.33 \pm 1.29 \mathrm{t} / \mathrm{ha})$ was higher in Middle Mountains than the stocks in lower belt of Churia and Terai physiographic regions. Even in similar forest types, there was more SOC in Middle Mountains than in Churia and Terai regions (DFRS, 2014a; 2014b cited in DFRS, 2015a). Similar result of SOC was found in the studied CFS, as all these sites are in the Middle mountains region.

\section{Total carbon stock}

Total forest carbon stock density is calculated by the addition of biomass carbon (Table 2) and soil organic carbon (Table 3). The AGBC, BGBC and SOC along with total carbon stock of three community forests are shown in figure 3 .

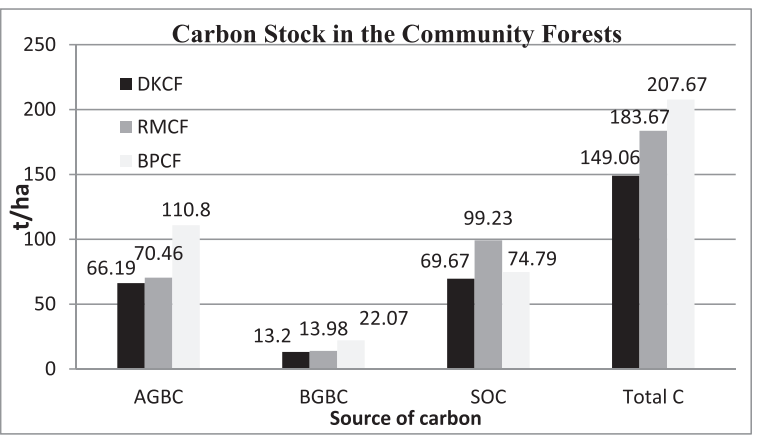

Fig. 3: Carbon stock density of studied three community forests

The highest carbon density was found in BPCF (207. $67 \mathrm{t} / \mathrm{ha}$ ) followed by RMCF (183. $67 \mathrm{t} / \mathrm{ha})$. Similarly, the lowest mean value of total carbon stock density of the DKCF was found to be 149 . $06 \mathrm{t} / \mathrm{ha}$. The highest carbon stock density in BPCF may be due to the presence of larger sized trees (older trees) and high accumulation of leaf litter.

In percentile, DKCF constituted the $44.40 \%$ AGBC, $8.87 \%$ BGBC and $46.73 \%$ SOC. The corresponding pools were $38.36 \%, 7.61 \%$ and $54.03 \%$ for RMCF and $53.35 \%, 10.65 \%$ and $36 \%$ for BPCF, respectively.

ANOVA test showed that there was significant $(p<0.05)$ difference in total carbon stock density between the community forests. The Tukey's HSD test showed that there was significant difference $(p>0.05)$ in mean carbon stock of BPCF with RMCF and DKCF but there was no significant difference $(p>0.05)$ in mean carbon stock between RMCF and DKCFs. The SOC of this study is lower than the SOC of CFs in Gorkha (234. $54 \mathrm{t} / \mathrm{ha}$ ) and Chitwan (479. $29 \mathrm{t} / \mathrm{ha}$ ) districts of the Mid-hills (Pandey and Bhusal, 2016) but higher than mean carbon stock of the Middle hills (138. 11t/ha) (DFRS, 2015a). The total carbon

Table 3 : Soil organic carbon, bulk density and $\mathrm{pH}$ of the community forests

\begin{tabular}{|l|c|c|c|c|c|c|}
\hline \multirow{2}{*}{$\begin{array}{c}\text { Community } \\
\text { forest }\end{array}$} & \multicolumn{3}{|c|}{ SOC (t/ha) } & \multirow{2}{*}{$\begin{array}{c}\text { Mean bulk density } \\
\text { (g/cm }\end{array}$} & \multirow{2}{*}{ SH } & \multirow{2}{*}{ SOC (t/ha) } \\
\cline { 2 - 4 } & $\mathbf{0 - 1 0}$ & $\mathbf{1 0 - 2 0}$ & $\mathbf{2 0 - 3 0}$ & & & \\
\hline DKCF & 26.65 & 22.86 & 20.15 & 0.97 & 5.03 & 69.67 \\
\hline RMCF & 38.73 & 32 & 28.47 & 0.88 & 5.25 & 99.23 \\
\hline BPCF & 30.49 & 23.79 & 20.43 & 0.93 & 5.06 & 74.79 \\
\hline
\end{tabular}


stock of RMCF and DKCF except BPCF were higher than national average (176.95 t/ha) (DFRS, 2015b) (Fig. 3). This scenario depicts the better management of community-managed forests with higher amount of carbon sequestration than other modalities of forests in the country.

\section{Correlation of biomass density and SOC with other properties}

Cumulative mean value of biomass density and SOC were tested against cumulative mean value of rest of the factors at a time. The test output is presented in table 4.

Very weak positive correlation was found between biomass density ( $\mathrm{t} / \mathrm{ha}$ ) with soil bulk density and it was not significant $(\mathrm{p}>0$. 05). However, there was significant $(p<0.05)$ negative correlation of biomass density with SOC and Phosphorus but no significant correlation with other parameters (Table 4). On contrary to this result, forest ecosystems store 20-100 times more $\mathrm{C}$ per unit area than croplands and hence play a critical role in reducing ambient $\mathrm{CO}_{2}$ levels, by sequestering atmospheric $\mathrm{C}$ in the growth of woody biomass through the process of photosynthesis and thereby increasing the SOC content (Brown and Pearce, 1994). The possible reasons behind negative relationship between biomass density and SOC are young forests and regular extraction of biomass from the forests due to which long time is needed to accumulate, decompose and convert biomass into SOC. Similarly, SOC has significant $(\mathrm{p}<0.05)$ correlation with all the parameters, however, soil bulk density has high degree $(r=-0.88)$ of negative correlation (Table 4). Biomass stock density (t/ha) (Table 2) has negative significant $(\mathrm{p}<0.05)$ relation with SOC and Phosphorous content in the soil (Table 4). This result revealed that the higher biomass in the forest facilitates the lesser amount of SOC and Phosphorus in the soil. Similarly, alkaline soils with higher contents of primary soil nutrients (NPK) have relatively higher SOC in forest soil whereas higher the soil bulk density, lesser the SOC in the community managed-forest of Nepal, especially in Dadeldhura district.

Table 4 : Correlation between biomass and SOC with other parameter in studied CFs

\begin{tabular}{|l|l|c|c|c|}
\hline S. N. & \multicolumn{1}{|c|}{ Test parameters } & $\begin{array}{c}\text { Correlation } \\
\text { coefficient }(\mathbf{r})\end{array}$ & P-value & $\begin{array}{c}\text { Significance } \\
\text { (Yes/No) }\end{array}$ \\
\hline 1 & Biomass density (t/ha) vs. SOC $(\mathrm{t} / \mathrm{ha})$ & -0.38 & 0.0096 & Yes \\
\hline 2 & Biomass density vs. soil bulk density $\left(\mathrm{gm} / \mathrm{cm}^{3}\right)$ & 0.23 & 0.1346 & No \\
\hline 3 & Biomass density vs. soil $\mathrm{pH}$ & -0.08 & 0.5824 & No \\
\hline 4 & Biomass density vs. N $\%$ & -0.22 & 0.1403 & No \\
\hline 5 & Biomass density vs. $\mathrm{P}(\mathrm{kg} / \mathrm{ha})$ & -0.56 & $7-\mathrm{e} 5$ & Yes \\
\hline 6 & Biomass density vs. K $(\mathrm{kg} / \mathrm{ha})$ & -0.29 & 0.054 & No \\
\hline 7 & SOCvs. soil bulk density $\left(\mathrm{gm} / \mathrm{cm}^{3}\right)$ & -0.88 & $3.72-\mathrm{e} 15$ & Yes \\
\hline 8 & SOCvs. soil $\mathrm{pH}$ & 0.35 & 0.0198 & Yes \\
\hline 9 & SOCvs. $\mathrm{N} \%$ & 0.43 & 0.0033 & Yes \\
\hline 10 & SOCvs. $\mathrm{P}(\mathrm{kg} / \mathrm{ha})$ & 0.76 & $1.068-\mathrm{e} 9$ & Yes \\
\hline 11 & SOC vs. $\mathrm{K}(\mathrm{kg} / \mathrm{ha})$ & 0.67 & $4.99-\mathrm{e} 7$ & Yes \\
\hline
\end{tabular}

Correlation coefficient (r) value ranges from -1 to +1 , negative value indicates the reciprocal relationship whereas positive value indicates proportional relationship between the test parameters. If the $r$ value is closer to extreme case, then it signifies the stronger association between the parameters and vice-versa. P-value indicates the significant level. If p-value is less than 0.05 , then it indicates that the test result is significant at 5\% level and vice-versa. 


\section{Conclusion}

Community-managed forests seemed a viable source of biomass production and carbon sink to combat the global environmental problem by local actions. These forests conserve the relatively more biomass (biomass carbon) than the normally managed forests in the country. The SOC decreased with increase in soil depths in the study area. The carbon density significantly varied from one $\mathrm{CF}$ to another $\mathrm{CF}$. Very weak positive correlation between biomass density ( $\mathrm{t} /$ ha) with soil bulk density revealed that the heavy soil catalyze the higher biomass production in the forests. However, significantly negative correlation between biomass density with SOC and Phosphorous contents in the soil indicates either organic carbon leached in sloppy terrain or uptake by the plants to produce biomass. Moreover, biomass density in the forests has no significant relation with soil $\mathrm{pH}$, Nitrogen percent in soil, Potassium content in CFs of Dadeldhura district. But SOC has significant relation with most of the soil properties. Reciprocal relation between SOC and bulk density means that the higher SOC was found in the lesser bulk density forest soil. Also, higher biomass in the forests facilitates the lesser amount of SOC and primary soil nutrients (NPK) in forests' soil. Similarly, acidic soil with high content of primary soil nutrients (NPK) has relatively higher SOC in forest soil. This result would be a reference to national and international community of diverse fields who are engaged in forest carbon services related activities such as reducing emission from deforestation and forest degradation (REDD), clean development mechanism (CDM). Similar studies have to be carried out covering larger geographical areas and different ecological zones to generalize the inference.

\section{References}

ANSAB. 2010. Forest carbon stock measurement : Guidelines for measuring carbon stocks in community managed forest. Asia Network for Sustainable Agriculture and Bioresources (ANSAB), Federation of Community Forest Users, Nepal (FECOFUN), International Centre for Integrated Mountain Development (ICIMOD), Norwegian Agency for Development Cooperation (NORAD).
Bajracharya, R. M., Lal, R. and Kimble, J. M., 1998. Soil organic carbon distribution in aggregates and primary particle fractions as influenced by erosion phases and landscape position. In Soil Processes and the Carbon Cycle (eds.) Lal, R., Kimble J., Follett. R and Stewart, B. A., CRC Press, Boca Raton, Florida, 353-367.

Brown, K. and Pearce, D. 1994. The Economic Value of Non Timber Benefits of Tropical Forests : Carbon Storage. In The Economics of Project Appraisal and the Environment; New Horizons in Environment Economics (ed.) Weiss, J., Chelttenham (UK) : Edward Elgar, Aldershot Publishing.

Chave, J., Andalo, C., Brown, S., Caims, M. A., Chambers, J. Q. and Eamus, D. 2005. Tree allometry and estimation of carbon stocks. Oecologia 145 (1) :87-99.

DFRS. 2015a. Middle Mountains Forests of Nepal. Forest Resource Assessment (FRA) Nepal, Department of Forest Research and Survey (DFRS). Kathmandu, Nepal.

DFRS. 2015b. State of Nepal's Forests. Forest Resource Assessment (FRA) Nepal, Department of Forest Research and Survey (DFRS). Kathmandu, Nepal. http ://dfrs. gov. np/downloadfile/state $\% 20 \mathrm{of} \% 20$ forest_1470140234.pdf.

DHM. 2016. Meteorological data of the districts. Department of Hydrology and Meteorology, Kathmandu, Nepal.

Dixon, R. K., Brown, S., Houghton, R. A., Solomon, A. M., Trexler, M. C. and Wisniewski, J. 1994. Carbon pools and flux of global forest ecosystems. Science $263: 185-190$.

DoFSC. 2018. Status of Community Forests Users' Groups. Department of Forests and Soil Conservation, Ministry of Forests and Environment, Babarmahal, Kathmandu, Nepal.

FAO. 2001. Soil carbon sequestration for improved land management. World Soil Resources Reports 96. FAO, Rome, Italy. 
FAO. 2011. FAO Glossary terms. Food and Agriculture Organization of the United Nations, Rome, Italy.

Geider R. J., Delucia, E. H., Falkowski, P. G. 2001. Primary productivity of planet earth :biological determinants and physical constraints in terrestrial and aquatic habitats. Global Change Biology 7 : 847882.

GoN. 1993. The Forest Act, 1993. Government of Nepal, Ministry of Law, Justice and Parliamentary Affairs, Law Books Management Committee, 2017.

GoN. 2015. The Constitution of Nepal, Kathmandu, Nepal : Government of Nepal, Ministry of Law, Justice and Parliamentary Affairs, Law Books Management Committee, 2015.

Guggenberger, G., Christensen, B. T. and Zech, W. 1994. Land-use effects on the composition of organic matter in particlesize separate of soil : I. Lignin and carbohydrate signature. European Journal of Soil Science 45 :449-458. https ://en. wikipedia. org/wiki/Dadeldhura_District. [Assessed on 2 August, 2018].

IPCC. 2000. Land use, land use change, and forestry : a special report of the IPCC. Cambridge University Press. Cambridge, UK.

IPCC. 2006. IPCC Guidelines for National Greenhouse Gas Inventories : Intergovernmental Panel on Climate Change, National Greenhouse Inventory Program. United Nations Environment Program (UNEP). http ://www. ipcc-nggip. iges. or. jp/ [Accessed on 2 August, 2018].

Jandle, R., Lindner, M., Vesterdal, L., Bauwens, B., Baritz, R., Hagedorn, F., Johnson, D. W., Minkkinen, K. and Byrne K. A. (2007). How strongly can forest management influence soil carbon sequestration? Geoderma 137 : 253-268

Jin, F., Yang, H. and Zhao, Q. 2000. Progress in the research of organic carbon storage. Soil
$32(1): 11-17$.

Kirschbaum, M. U. F. 1996. The carbon sequestration potential of tree plantations in Australia. In Environmental Management : The Role of Eucalypts and Other Fast Growing Species (eds.) Eldridge, K. G., Crowe, M. P. and Old, K. M, CSIRO Forestry and Forest Products, 77-89.

Lal, R. 2004. Soil carbon sequestration to mitigate climate change. Geoderma 123 (1-2) :1-22

Lamsal, P., Kumar, L., Atreya, K. and Pant, K. P. 2018. Forest ecosystem services in Nepal : a retrospective synthesis, research gaps and implications in the context of climate change. International Forestry Review 32 :506-537.

Lepetz, V., Massot, M., Schmeller, D. S. and Clobert, J. 2009. Biodiversity monitoring :someproposals to adequately study species's responses to climate change. Biodiversity and Conservation 18 :3185. https ://doi. org/10. 1007/s10531-0099636-0.

MacDicken, K. 1997. A Guide to Monitoring Carbon Storage in Forestry and Agro forestry Projects Arlington (VA). Forest Carbon Monitoring Programme, Winrock International Institute for Agriculture Development.

Oli, B. N. and Shrestha, K. 2009. Carbon status in forests of Nepal : An overview. Journal of Forest and Livelihood 8 (1) :63-67.

Pandey, H. P. and Bhusal, M. 2016. A comparative study on carbon stock in Sal (Shorearobusta) forest in two different ecological regions of Nepal. Banko Janakari 26 (1) :24-31. https :/www. nepjol. info/index. php/BANKO/ article/download/15498/12505.

Pearce, D. W., Putz, F. and Vanclay, J. K. 2003. Sustainable Forestry in the Tropics : panacea or folly ? Forest Ecology and Management 172 (2-3) :229-247.

Pearson, T. R., Brown, S. L. and Birdsey, R. A. 2007. Measurement guidelines 
for the sequestration of forest carbon. Northern Research Station, Department of Agriculture, USA.

R Core Team. 2018. R : A language and environment for statistical computing. R Foundation for Statistical Computing, Vienna, Austria.

Rasse, D. P., Mulder, J., Moni, C. and Chenu, C. 2006. Carbon turnover kinetics with depth in a French loamy soil. Soil Sci. Soc. Am. J. 70 (6) : 2097-2105. doi : 10. 2136/sssaj 2006.0056 .

Shrestha, B. M. and Singh, B. R. 2008. Soil and vegetation carbon pools in a Mountain Watershed of Nepal. Nutrient Cycling in Agro ecosystems 81 : 179-191.

Shrestha, B. P. 2008. Carbon sequestration in Schima-Castanopsis Forest : A case study from Palpa District. The Greenery-a journal of Environment and Biodiversity 7 (1) : 34-40.
Tamrakar, P. R. 2000. Biomass and Volume Tables with species Description for Community Forest Management. Tree improvement and Silviculture Component, Kathmandu, Nepal.

UNFCCC. 2010. Draft decision-/CP. 16: Outcome of the work of the Ad Hoc Working Group on Long-term Cooperative Action under the United Nations Framework Convention on Climate Change, 2010.

Van Noordwijk, M., Cerri, C., Woomer, P. L., Nugroho, K. and Bermoux, M. 1997. Soil carbon dynamics in the humid tropical forest zone. Geoderma. $79: 187-225$. 